\title{
OECD DAC Gendernet 공동워크숍 및 비공식회의 결과
}

OECD 개발원조위원회(DAC) Gendernet 회의가 2010.2.1-3간 오스트리아 빈에서 개최되었다. 본 회의에서는 여성의 경제역량강화 이슈의 맥락에서 수원국 주인의식 확립 및 원조책무성 강화 방안, DAC 성평등네트워크 활동 성과 등에 대해 논의되었다. 동 회의에는 KOICA 정책연구실 김진 영대리가 참석하여 아래와 같이 회의 주요 내용을 정리, 보고하였다.

\section{I. 핵심 요지}

\section{1. 공동 워크숍}

가. 공동 워크숍 배경 및 의의

금번 워크숍은 개발에 대한 수원국 주인의식 수립과 다양한 개발주체의 책무성 확보 메카니즘의 다 층성의 측면에서 방대한 사례연구와 심화토론을 통해 여성의 경제역량을 강화하기 위한 방안을 모 색함. 주요 개발목표로서의 성평등을 달성하기 위해 여성의 경제적 자립과 역량강화는 필수적인 바, 동 워크숍을 통한 실질적 정책과제 도출 노력은 시의적절한 것으로 사료됨.

리차드 캐리 $\mathrm{OECD} / \mathrm{DCD}$ 국장은 최근의 식량 - 금융위기로 가속화되는 도농인구 이주 등 인구혁명 (demographic revolution)이 노동시장의 구성과 소득창출의 형태에 지대한 변화를 가져오고, 이는 여성의 경제역량강화 이슈와 밀접한 연관을 지니는 바, $\mathrm{OECD} / \mathrm{DAC}$ 는 주요 우선순위를 가지고 성 평등 이슈를 다루고 있다고 밝힘. 한편, Kandeh Yumkella UNIDO 사무총장은 개도국의 산업개발 에 있어 여성의 경제역량 강화가 중요함을 강조하였고, Rachel Mayanja UNIANWGE 의장은 동 이슈에 대한 국제사회의 공약과 실제 수원국의 국가정책간의 괴리를 지적하면서 주인의식과 책무 성에 대한 논의의 중요성을 환기함.

나. 여성의 경제역량강화를 위한 새로운 접근 방법 모색 
여성의 경제역량강화는 돌봄경제(care economy)와 병행하여 논의되어야하며, 사회 · 정치 · 문화 등 다른 차원의 역량강화와의 연계도 모색해야함. 또한, 사회안전망(social protection)의 구축은 여성의 경제적 자립과 사회적 변화를 위해 중요함.

단순한 노동시장 참여와 창업의 확대는 생산과 재생산 부문에서의 균형잡힌 분배로 이어지지 않고, 인권차원의 접근이 요구됨. 품위있는 직업(decent work)에의 권리 확대, 노동환경 개선, 무임금 노 동을 포함한 여성의 노동에 대한 인식과 가치부여가 중요함. 특히, 토지 및 경제적 자산에 대한 접 근성, 소유, 활용에 대한 권리는 경제위기시 여성의 경제적 자립과 안전을 확보하기 위한 핵심적인 요소로 작용함.

\section{다. 경제정책의 여성 우호 패러다임 전환 요구}

거시투자정책이 주로 남성을 대상으로 이루어지는 한편, 여성을 대상으로는 소금융정책 (microfinance)이 시행되면서 경제구조의 불균형이 발생함. 기존 소금융정책 모델의 수정과 규모 확대가 필요하며 농촌지역의 전기시설, 도로 등 여성의 필요에 부응하는 인프라시설의 투자가 요구 됨.

한편, 여성에게도 혜택이 가는 무역을 위한 원조(aid for trade) 체계 구축이 필요함. 다자적 무역 체계와 전지구적 가치 생산 체인(global value chain)에 여성이 질적으로 기여할 수 있는 정책적 제도적 바탕을 구축하는 것이 중요함. 민관협력의 확대와 기존 시장경제 참여 여성이 잠재성을 발 휘할 수 있는 조건(농촌생산자와 도시 사업자의 연계 강화 등)을 형성하고, 농촌지역 빈곤여성의 경 제적 자립문제에 대해서도 관심을 기울여야함.

\section{라. 주인의식과 상호책무성 강화 중요}

수원국의 주인의식은 다양한 관점과 참여하는 개발주체에 따라 복합적이고 점진적으로 형성됨. 그 러나 공여국 및 국제사회 등 외부에서 부여하는 과도한 조건 및 개발과제의 일방적 추진은 수원국 의 완전한 주인의식(full ownership) 형성을 저해하고 여성의 경제역량강화 노력의 정착과 내재화 를 더디게 할 수 있으므로 주의를 기울여야함.

책무성도 다층적인 이해관계자를 포함하고 있고, 수원국의 책무성 뿐 아니라 국제적 공약에 대한 공여국의 책무성 등 상호책무성 강화가 중요함. 개발재원의 예측가능성은 공여국측의 책무성을 판 단하는 주요 기준이 되며 개발원조의 일관성과 지속성을 확보하여 상호책무성을 도모하는 노력을 경주해야함. 


\section{마. 대내외적 책무성 모니터링 메카니즘 개발 필요}

개발재원의 집행대상과 방법의 모니터링은 책무성 확립, 투명성 확보, 결과중심의 관리(managing for development results)를 위한 주요 도입점(entry point)이 됨. 정책 및 예산을 심의하는 국회 는 책무성 강화 노력을 위한 핵심적인 기관으로 기능하므로 수원국과 공여국 양 국회활동의 성 주 류화 노력이 매우 중요함. 또한, 젠더 이슈에 대한 정책결정자의 책무성 내재화를 위해 인센티브 도 입이 시급함.

한편, 개발지표의 젠더화(engendering) 연구에 대한 필요성과 더불어 현재 여러 공여기관에서 개 발, 활용하는 다양한 젠더마커에 대한 활발한 논의가 진행됨. $\mathrm{OECD/DAC} \mathrm{젠더마커를} \mathrm{비롯한} \mathrm{여러}$ 젠더마커가 젠더 영향(gender impact)을 측정할 수 없다는 한계점이 지적이 되었으나, 성평등 달 성을 위해 분배되는 개발재원의 규모가 작거나 젠더 관련 공약이 실제 집행과 연계되지 않는 경우, 젠더마커를 활용하여 실질적인 집행실적을 모니터링하는 것은 의의가 있음. 다만, 통일된 형식과 질적 성과를 측정할 수 있는 지표의 개발 및 마커를 작성하는 담당자의 책무성 확보 필요성에는 공 감함. 아울러, 사무국은 마커의 객관성 개선에 대해 추가적으로 논의하기로 함.

\section{2. 비공식 회의}

\section{가. 성평등네트워크 2011-2012 PWB 검토}

금년 6.30일 승인 예정인 DAC 2011-2012 PWB (Program of Work \& Budget) 초안은 예산 규 모가 3천만 유로이며, 3 개 $\mathrm{DAC}$ 핵심분야(통계, 동료검토, 원조효과성)와 4개 주요 우선순위(분 쟁 · 취약국, 경제성장, 글로벌 개발 거버넌스, 기후변화)를 규정함. 이와 관련, 성평등네트워크 사 무국은 97만 유로 예산규모로 3개 핵심분야 및 3개 주요 우선순위(기후변화 제외)에서의 작업방향 을 마련하였고, 회원국은 이에 대해 논의함.

회원국은 향후 성평등네트워크의 비교우위를 특화하고 지속적으로 강화할 필요성을 강조함. 특히, 개발원조 젠더이슈 관련 공여기관, 국제기구 및 전문가의 소집역량(convening power)은 타 산하 작업반보다 월등함을 높이 평가하였고, 혁신적인 리더십 발휘 및 선도적인 이니셔티브를 추진해온 것이 동 작업반의 영향력 확대의 원동력이 된 것을 감안, 지적산출물의 부가가치 생산에 주력하고, 타 산하작업반과의 활동 연계를 확대하며, 본부 및 현장에서의 책무성을 강화하기 위해 작업반 구 성원들이 더 많은 노력을 경주해야함을 역설함. 


\section{나. 성평등네트워크 TF 작업경과 점검}

(원조효과성 $\mathrm{TF}$ ) 작업반은 작년 10 월 $\mathrm{TF}$ 회의시 파리선언의 집행성과 평가지표가 젠더 관점을 반영 하지 않은 것을 지적한 바 있음. 이에 따라 $\mathrm{DAC}$ 원조효과작업반(WP-EFF)와 공조하여 원조효과 와 성평등 달성 목표를 평가하기 위한 지표를 개발할 결과, 3 개 부문(개발전략, 성과측정 프레임워 크, 상호책무성)에서 지표가 산출됨. 동 지표는 원조효과성 평가시 유용한 젠더 평가 포인트(entry point)로 기능하고, 아울러 $\mathrm{HLF}-4$ 및 이후 원조평가작업시 효과적인 논의자료로 활용될 것으로 기대됨.

아울러, 작년 6월 총회 의제인 성 인지 예산을 통한 수원국시스템 활용방안 논의의 정책산출물로 서 개발원조와 성 인지 예산에 대한 Issues Brief 6호의 초안이 완성됨. Issues Brief는 동 작업반 발간 정책 페이퍼로서 사무국은 동 초안을 회원국에 회람, 금월 말까지 검토의견을 수렴할 계획임.

(여성 경제역량강화 $\mathrm{TF}$ ) $\mathrm{DAC}$ 빈곤퇴치작업반(POVNET)의 역량강화 $\mathrm{TF}$ 는 15 페이지 분량의 성과 사례집을 작성 중이며, 여성의 경제역량강화 부문에서 성평등네트워크와 공조하여 작업을 진행 중 임. 특히, 금번 워크숍에서 논의된 사회적 보호, 무역을 위한 원조, 품위있는 직업 이슈는 POVNET $\mathrm{TF}$ 작업과 밀접한 연관을 가지고 있음. 향후 다양한 주제의 성과사례집을 발간할 시에도 성평등네 트워크와의 긴밀한 협력을 기대함.

\section{II. 관찰 및 건의}

\section{1. 본 워크숍의 의의}

개발에 대한 수원국 주인의식 수립과 다양한 개발주체의 책무성 확보 메카니즘의 다층성 측면에서 방대한 사례연구와 심화토론을 통해 여성의 경제역량을 강화하기 위한 방안을 모색함. 주요 개발목 표로서의 성평등을 달성하기 위해 여성의 경제적 자립과 역량강화는 필수적인 바, 동 워크숍을 통 한 실질적 정책과제 도출 노력은 시의적절한 것으로 사료됨. 


\section{2. 공여국 책무성 강화}

동 워크숍은 여성의 경제적 역량강화를 위해 수원국 뿐 아니라 공여국의 책무성 강화가 필요함을 거듭 강조한 바, 이에 따른 정책적 방향과 사업집행전략을 마련해야함. 젠더 관련 KOICA의 정책 방향과 전략을 반영한 국별지원전략과 성 인지 예산서의 작성, 젠더마커 작성담당자의 책무성을 형 성하기 위한 마커 이해 제고 교육 강화 및 품질관리 방안 마련, 금번 성평등네트워크에서 개발한 파 리선언 젠더 지표의 적극 활용 등 $\mathrm{KOICA}$ 의 책무성 강화를 위한 노력을 경주해야함.

\section{3. 정책연구 확대}

$\mathrm{DAC}$ 우선순위 분야에 대한 정책연구를 강화하고 관련 활동에 적극 참여하여 신규회원국으로서 적 극적이고 능동적인 참여와 기여가 요구됨. 특히, 주요 연구과제로서 경제성장 및 분쟁·취약국 이슈 와의 젠더 관점 접목 연구가 시의적절할 것으로 사료됨.

국제사회는 경제 위기에 더 취약한 여성의 경제적 자립과 역량 강화 방안으로서 무역을 위한 원조 (AfT)의 맥락에서 논의를 진행 중임. 한편, 금번 아이티 사태를 계기로 금년 1월 유엔 64 차 총회에 서 채택한 '국제긴급구호 부문의 원조의 개발 전환' 결의문은 긴급원조의 성 주류화의 중요성을 강 조하고 관련 기관이 정책 및 사업수행시 성 주류화를 추진토록 독려함.

\section{4. 국제사회 논의 적극 참여}

금년은 베이징행동강령 채택 15 주년, MDG 제정 10 주년, 분쟁 및 취약상황에서의 여성의 권리 보 호를 위한 유엔 결의문 1325 채택 10주년 등 여성의 역량강화와 성평등 관련 국제사회 주요 공약 을 기념하는 뜻깊은 시기임. 이에 따라, 유엔 여성지위위원회(CSW)는 뉴욕 유엔본부에서 3.1-12 일간 54회 총회를 개최하여 베이징 +15 및 $\mathrm{MDG}$ 이행성과, 결의문 1325 에 대한 중간 평가를 실시 할 예정임. 금번 회의는 개발원조에서의 젠더 정책방향 및 집행 논의의 주요 이정표가 될 것으로 전 망되는 바, $\mathrm{KOICA}$ 의 동 회의 참여를 통한 적절한 정책과제 도출 및 전략수립이 요구됨.

\section{5. 상주 젠더 전문가 확보 필요}

KOICA는 금년부터 성 인지 예산 및 '성인지담당관’ 직제를 도입하여 성 인지적 원조정책 수립과 제도 구축을 통해 $\mathrm{ODA}$ 사업의 성 주류화를 추진할 계획임. 이에 따라, 관련 정책 수립, 정책과 집 행 간의 효과적인 연계를 위한 젠더 가이드라인의 개발, $\mathrm{KOICA}$ 임직원 및 사업수행자 교육, 관련 정책연구 수행 및 자문 등을 실시할 상주 젠더 전문가의 확보를 통해 $\mathrm{KOICA}$ 의 효과적인 성 주류화 를 도모할 필요가 있음. 